\title{
BRPKM
}

Buletin Riset Psikologi dan Kesehatan Mental

http://e-journal.unair.ac.id/index.php/BRPKM

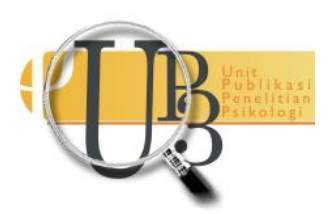

ARTIKEL PENELITIAN

\section{Pengaruh Academic Self-efficacy terhadap Academic Burnout Pada Mahasiswa yang Sedang Mengerjakan Skripsi}

\author{
AYU ANGGRAINI WASITO \& NONO HERY YOENANTO*
}

Departemen Psikologi Pendidikan dan Perkembangan, Fakultas Psikologi Universitas Airlangga

\begin{abstract}
ABSTRAK
Hambatan mengerjakan skripsi menyebabkan mahasiswa mengalami kemunduran dalam proses penyelesaian dan secara tidak sadar mereka mengalami academic burnout. Hipotesis penelitian yaitu terdapat pengaruh academic self-efficacy terhadap academic burnout pada mahasiswa yang sedang mengerjakan skripsi. Penelitian ini menggunakan teknik purposive sampling. Teknik pengumpulan data menggunakan survei dengan menyebarkan kuesioner online. Dua skala dari academic self-efficacy dan academic burnout diberikan kepada 179 mahasiswa Fakultas Psikologi Universitas Airlangga yang sedang mengerjakan skripsi. Reliabilitas skala academic self-efficacy 0,919 dan reliabilitas skala academic burnout 0,928. Teknik analisis data menggunakan teknik regresi linear sederhana dengan SPSS 25 for Windows. Nilai koefisien regresi sebesar -0,821, taraf signifikansi sebesar 0,000 dan nilai $R$ Square sebesar 0,600. Hasil menunjukkan adanya pengaruh negatif dan signifikan, sehingga semakin tinggi academic self-efficacy maka semakin rendah academic burnout dan sebaliknya. Pengaruh academic self-efficacy terhadap academic burnout sebesar $60 \%$ dan $40 \%$ dipengaruhi variabel lain tidak diteliti.
\end{abstract}

Kata kunci: academic burnout, academic self-efficacy, mahasiswa

\begin{abstract}
Obstacles in doing thesis cause college students to decrease in the completion process and they unconsciously suffered academic burnout. The hypothesis that there is an effect of academic self-efficacy on academic burnout in college students in doing their thesis. The purposive sampling technique and survey by distributing online questionnaires. Two scales of academic self-efficacy and academic burnout were given to 179 students of the Faculty of Psychology Universitas Airlangga in doing their thesis. The reliability of the academic self-efficacy scale and academic burnout scale is 0.919 and 0.928 . The simple linear regression technique with SPSS 25 for Windows. The regression coefficient is -0.821 , the significance is 0.000 and the $\mathrm{R}$ Square is 0.600 . The result is a negative effect significant, so the higher academic self-efficacy, the lower academic burnout and otherwise. The effect of academic self-efficacy on academic burnout is $60 \%$ and $40 \%$ of other variables not studied.
\end{abstract}

Keywords: academic burnout, academic self-efficacy, college students

Buletin Penelitian Psikologi dan Kesehatan Mental (BRPKM), 2021, Vol. 1(1), 112-119

*Alamat korespondensi: Fakultas Psikologi Universitas Airlangga, Kampus B Universitas Airlangga Jalan Airlangga 4-6 Surabaya 60286. Surel: nono.hery@psikologi.unair.ac.id 
sehingga penggunaan, distribusi, reproduksi dalam media apapun atas artikel ini tidak dibatasi, selama sumber aslinya disitir dengan baik.

\section{PE N D A H U L U A N}

Setiap mahasiswa dituntut untuk menyelesaikan studinya dalam jangka waktu yang telah ditentukan. Mahasiswa yang dapat lulus tepat waktu mendapatkan beberapa keuntungan yaitu bisa memulai karir lebih awal. Mahasiswa yang memasuki perkuliahan usia 18 tahun dan usia 21 tahun mendapatkan gelar sarjana, serta usia 22 tahun memasuki dunia kerja yang merupakan usia produktif untuk memulai karir (Idntimes, 2020). Sama halnya dengan Negara Filipina yang mana usia lulusan yang bekerja sebagian besar berada pada kelompok usia 20-23 tahun. Hal tersebut menunjukan sebagian besar lulusan yang bekerja menyelesaikan pendidikan tepat waktu yaitu 48,5\% sedangkan usia 24-27 sebesar 42,6\% (Arcelo \& Sanyal, 1987).

Pencapaian gelar sarjana memerlukan proses yang harus ditempuh, salah satunya dengan menyelesaikan tugas akhir yaitu skripsi. Sehingga mahasiswa yang sedang mengerjakan skripsi dituntut untuk segera merampungkannya. Puspitaningrum (2018) mengungkapkan bahwa tuntutan yang diterima mahasiswa berasal dari orang tua, dosen pembimbing, akademik, teman-teman dan diri sendiri untuk ingin segera menyelesaikan studinya. Sehingga dalam mengerjakan skripsi dapat menguras tenaga dan pikiran setiap mahasiswa. Berbagai tuntutan tersebut memacu tiap mahasiswa untuk cepat dalam mengerjakan skripsi dan segera meraih gelar sarjana. Akan tetapi dalam kenyataannya, banyak tantangan dan hambatan bagi mahasiswa yang mengerjakan skripsi.

Peneliti melakukan survei online memalui media Instagram Story mengenai hambatan yang dialami mahasiswa yang sedang mengerjakan skripsi Fakultas Psikologi Universitas Airlangga. Hasil dari survei tersebut dianalisis secara deskriptif, sehingga menghasilkan 34 dari 41 mahasiswa mengalami beberapa hambatan. Mahasiswa Fakultas Psikologi Universitas Airlangga dapat mengalami satu atau lebih hambatan yang dapat dirangkum meliputi kesulitan menentukan topik atau judul skripsi, kesulitan mencari literatur atau bahan kajian, merasa cemas ketika berhadapan dengan dosen pembimbing, merasa lelah karena adanya revisi yang tak kunjung selesai, merasa topik skripsi tidak lebih baik dari yang lain, merasa bingung untuk memulai pekerjaan, merasa tidak fokus dalam mengerjakan tugas, merasa kurang puas dengan pekerjaan, merasa tidak mempunyai waktu yang cukup dalam mengerjakan tugas dan merasa cemas akan hasil akhir yang tidak sesuai harapan. Dari hasil tersebut sesuai dengan penelitian JJ Siang (dalam Julita, 2015) hambatan yang dihadapi mahasiswa yang mengerjakan skripsi terdiri dari dua faktor yaitu faktor internal meliputi kesulitan menentukan topik atau judul skripsi, dan kurangnya minat atau motivasi dalam diri untuk segera menyelesaikan skripsi. Faktor eksternal yaitu kesulitan mencari literatur atau bahan kajian dan merasa cemas ketika berhadapan dengan dosen pembimbing.

Mahasiswa dalam menempuh skripsi rentan mengalami lelah dan stres. Mahasiswa yang mengalami lelah dan stres dari pekerjaan yang sedang dilakukannya dapat mengarah pada kelelahan dan kejenuhan yang dalam kajian ilmu psikologi dapat disebut dengan istilah academic burnout (Hu \& Schaufeli, 2009). Berdasarkan temuan tersebut peneliti melakukan studi awal mengenai academic burnout pada tanggal 23-30 Februari 2020. Studi awal dilakukan dengan menyebar kuesioner online mengenai gejala-gejala academic burnout menurut Freudenberger dan richelson (dalam Khairani \& Ifdil, 2015), yaitu keletihan yang disertai dengan proses kehilangan energi, berusaha mencari kegiatan lain, tidak tertarik mengerjakan skripsi, mudah marah ketika menghadapi hambatan skripsi, merasa mampu menyelesaikan skripsi, merasa hasil yang didapat tidak dihargai, merasa hasil yang didapat tidak sesuai harapan, sering mengalami sakit kepala, mual-mual dan gangguan fisik lainnya, merasa curiga dengan 
orang lain, depresi, merasa gagal dan takut untuk menghadapi masalah. Kuesioner tersebut menggunakan skala likert mulai dari 1 artinya "sangat tidak setuju", 2 "tidak setuju", 3 "setuju" dan 4 "sangat setuju". Sampel yang diambil sebanyak 71 partisipan meliputi 20 laki-laki dan 51 perempuan.

Hasil data yang diperoleh peneliti yaitu sebagian besar mahasiswa mengalami gejala academic burnout pada tingkat sedang sebanyak 27 mahasiswa atau sebesar 38\% dan 20 mahasiswa pada tingkat tinggi atau sebesar 28,2\%. Sesuai dengan penelitian sebelumnya Puspitaningrum (2018) bahwa mahasiswa yang sedang mengerjakan skripsi mengalami academic burnout tingkat sedang sebesar 61,25\%.

Maslach dkk. (2001) menjelaskan bahwa burnout terdiri dari 2 faktor yaitu faktor situasional dan faktor individual. Faktor situasional meliputi karakteristik pekerjaan, karakteristik jabatan dan karakteristik organisasi. Faktor individual terdiri dari karakteristik demografis, karakteristik kepribadian dan sikap kerja. Salah satu karakter kepribadian yaitu academic self-efficacy yang sesuai dengan penelitian Durán dkk. (2006) menambahkan bahwa salah satu penyebab academic burnout karena adanya perbedaan individu dalam karakteristik disposisional mahasiswa, yang artinya bahwa academic self-efficacy secara umum merupakan prediktor penting dalam keterlibatan mahasiswa yang mengalami academic burnout. Penelitian Fernández-Arata dkk. (2017) faktor prediktor yang dapat mempengaruhi academic burnout pada mahasiswa yaitu salah satunya academic self-efficacy.

Berdasarkan beberapa penelitian tersebut terlihat bahwa academic self-efficacy menjadi salah faktor yang memiliki kontribusi besar dan konsisten menjelaskan academic burnout dibandingkan dengan faktor lainnya. Mahasiswa dengan academic self-efficacy yang tinggi tidak mudah menyerah dan mencoba menemukan solusi yang tepat untuk memecahkan masalah ketika mahasiswa tersebut dihadapkan pada masalah akademik seperti mengerjakan skripsi (Arlinkasari \& Akmal, 2017). Mahasiswa yang memiliki academic self-efficacy yang memadai dapat melindungi diri dari potensi academic burnout. Rahmati (2015) academic self-efficacy memiliki hubungan negatif dan signifikan dengan academic burnout. Sesuai dengan penelitian Arlinkasari \& Akmal (2017) menunjukan bahwa jika mahasiswa mengalami academic burnout, maka mahasiswa tersebut memiliki academic self-efficacy yang rendah. menunjukan bahwa jika mahasiswa mengalami academic burnout, maka mahasiswa tersebut memiliki academic self-efficacy yang rendah. Berdasarkan uraian diatas, tujuan dari penelitian ini untuk mengetahui pengaruh academic self-efficacy terhadap academic burnout pada mahasiswa yang sedang mengerjakan skripsi di Fakultas Psikologi Universitas Airlangga.

\section{ME T O D E}

\section{Desain Penelitian}

Penelitian ini menggunakan pendekatan kuantiatif. Bentuk penelitian ini yaitu eksplanatori dimana menjelaskan sebab dan/atau sumber dari suatu perilaku sosial, kondisi, keadaan maupun suatu kejadian tertentu (Neuman, 2007).

\section{Partisipan}

Populasi penelitian ini yaitu mahasiswa Fakultas Psikologi Universitas Airlangga yang mengambil mata kuliah skripsi sebesar 323 mahasiswa. Partisipan dalam penelitian ini menggunakan rumus perhitungan Isaac dan Michael (Sugiyono, 2015). Berdasarkan rumus tersebut menghasilkan jumlah partisipan minimal sebesar 176 mahasiswa dan partisipan yang didapat dalam penelitian ini yaitu 179 
mahasiswa. Teknik pengambilan data menggunakan survei dengan purposive sampling. Partisipan berdasarkan syarat-syarat tertentu yaitu mahasiswa Fakultas Psikologi Universitas Airlangga, mahasiswa angkatan 2014-2017, Mahasiswa sedang mengerjakan skripsi. Pengambilan data diawali dengan bagian informed consent yang berisi pernyataan kesediaan partisipan dalam mengisi data dengan keadaan diri sesungguhnya. Partisipan didominasi oleh mahasiswa perempuan dengan jumlah 139 mahasiswa atau 77,7\%, sedangkan mahasiswa laki-laki sebesar 40 mahasiswa atau 22,3\% dari total partisipan. Partisipan didominasi mahasiswa angkatan 2017 sebesar 54,2\% atau 97 mahasiswa.

\section{Pengukuran}

Penelitian ini menggunakan alat ukur yang disusun sendiri oleh peneliti. Kedua skala sudah melalui tahap uji coba kepada 30 mahasiswa dan telah melewati proses diskriminasi. Sehingga menghasilkan skala academic self-efficacy yaitu dikembangkan berdasarkan teori (Bandura, 1997) dengan terdiri 22 item dan skala academic burnout dikembangkan berdasarkan teori (Hu \& Schaufeli, 2009) dengan terdiri 21 item. Penelitian ini menggunakan skala Likert dengan skor rentang jawaban 1 sampai 4 skala yang mana skor 1 artinya "sangat tidak sesuai", 2 artinya "tidak sesuai", 3 artinya "sesuai", 4 artinya "sangat sesuai". Uji reliabilitas dalam penelitian ini menggunakan teknik Cronbach's alpha untuk kedua skala yaitu skala academic self-efficacy (22 aitem; $\alpha=0,919)$ dan reliabilitas skala academic burnout (21 aitem; $\alpha=0,928)$.

\section{Analisis Data}

Teknik analisis data menggunakan teknik regresi linear sederhana dengan SPSS 25 for Windows. Uji analisis regresi linear sederhana bertujuan mengetahui besarnya pengaruh satu variabel bebas terhadap variabel terikat. Syarat melakukan uji regresi linier sederhana harus melakukan uji asumsi terlebih dahulu diantaranya yaitu uji normalitas, uji linieritas dan uji heterosdekastisitas. Jika data yang diuji normal, linier dan tidak ada perbedaan variasi atau heterosdekastisitas, maka data tersebut dapat dilanjutkan untuk diuji pengaruhnya menggunakan uji regresi linier sederhana.

\section{HAS IL PENELIT IAN}

Penelitian ini menggunakan analisis deskriptif statistik dengan bantuan perangkat lunak SPSS 25 for Windows. Hasil analisis deskriptif statistik pada variabel academic self-efficacy yaitu $(N=179 ; M=62,01$; $S D=1,729)$ dan pada variabel academic burnout yaitu $(N=179 ; M=53,28 ; S D=12,422)$. Hasil analisis deskriptif tersebut digunakan untuk mengukur tingkat atau kategori partisipan pada masing-masing variabel. Kategori partisipan pada skala academic self-efficacy menunjukkan bahwa kategori sangat rendah sebanyak 11 mahasiswa atau sebesar 6,1\%, kategori rendah sebanyak 43 mahasiswa atau sebesar 24\%, kategori sedang sebanyak 71 mahasiswa atau sebesar 39,7\%, kategori tinggi sebanyak 40 mahasiswa atau sebesar 22,3\%, kategori sangat tinggi sebanyak 14 mahasiswa atau sebesar 7,8\%. Sehingga sebagian besar mahasiswa mengalami academic self-efficacy kategori sedang.

Kategori partisipan pada skala academic burnout menunjukkan bahwa kategori sangat rendah sebanyak 15 mahasiswa atau sebesar 8,4\%, kategori rendah sebanyak 45 mahasiswa atau sebesar 25,1\%, kategori sedang sebanyak 60 mahasiswa atau sebesar 33,5\%, kategori tinggi sebanyak 49 mahasiswa atau sebesar 27,4\%, kategori sangat tinggi sebanyak 10 mahasiswa atau sebesar 5,6\%. Sehingga sebagian besar mahasiswa mengalami academic burnout kategori sedang. 


\section{Analisis Regresi}

Sebelum melakukan uji hipotesis, penulis melakukan uji asumsi terlebih dahulu sebagai syarat untuk melakukan uji regresi. Adapun uji normalitas dalam penelitian ini dengan kolmogorov-smirnov yaitu menghasilkan signifikan sebesar 0,200 yang berarti data yang diperoleh berdistribusi normal. Uji linieritas menghasilkan signifikan 0,000 yang berarti data yang diperoleh bersifat linier. Serta uji heterosdekastisitas menghasilkan signifikansi lebih dari 0,05 yaitu 0,553 yang berarti data yang diperoleh tidak terjadi ketidaksamaan variasi dari nilai residual satu pengamatan ke pengamatan lain, sehingga baik untuk melakukan uji regresi linier sederhana.

Hasil uji regresi linier sederhana dapat dilihat bahwa variabel academic self-efficacy ( $B=-0,821, S E=0,050$, nilai $\mathrm{p}<0,05)$ variabel independen memiliki pengaruh terhadap variabel dependen. setiap penambahan $1 \%$ tingkat academic self-efficacy (x), maka academic burnout akan meningkat sebesar -0,821. Karena nilai koefisien regresi bernilai minus (-), maka dengan demikian dapat dikatakan bahwa academic selfefficacy memiliki pengaruh negatif terhadap academic burnout. Besarnya pengaruh variabel independen terhadap variabel dependen dapat dilihat pada nilai R Square atau $R^{2}$ yang terdapat pada hasil SPSS 25 bagian Model Summary. Berdasarkan tabel tersebut, diketahui bahwa nilai R Square sebesar 0,600 yang dapat diartikan bahwa pengaruh academic self-efficacy terhadap academic burnout adalah sebesar $60 \%$, sedangkan 40\% academic burnout dipengaruhi oleh variabel lain yang tidak diteliti.

\section{I S K U S I}

Berdasarkan hasil analisis deskriptif dalam penelitian ini menunjukan bahwa mahasiswa yang sedang mengerjakan skripsi didominasi oleh perempuan sebesar 77,65\%. Hal tersebut sesuai dengan jumlah populasi yang mana sebagian besar didominasi oleh mahasiswi (Ristekdikti, 2019). Pengkategorian partisipan berdasarkan skor penormaan pada variabel academic self-efficacy sebagian besar partisipan termasuk ke dalam kategori sedang sebesar 39,7\% atau 71 mahasiswa, baik partisipan yang berjenis kelamin laki-laki maupun perempuan. Sesuai dengan penelitian Prianto (2010) mahasiswa yang sedang mengerjakan skripsi dari salah satu universitas di yogyakarta memiliki academic self-efficacy tingkat sedang yang artinya mahasiswa dalam mengerjakan skripsi menunjukkan gejala-gejala academic selfefficacy dalam tingkat sedang. Pengkategorian partisipan berdasarkan skor penormaan pada variabel academic burnout menghasilkan kategori sedang yaitu sebanyak 60 mahasiswa atau sebesar 33,5\%. Temuan tersebut sesuai dengan penelitian sebelumnya dilakukan oleh Puspitanigrum (2018) dan Sigit (2019) yang dilakukan menunjukkan bahwa mahasiswa yang sedang mengerjakan skripsi mengalami academic burnout tingkat sedang.

Hasil analisis regresi menunjukkan signifikan dan nilai koefisien regresi bernilai minus (-), maka dengan demikian dapat dikatakan bahwa academic self-efficacy memiliki pengaruh negatif terhadap academic burnout. Sehingga dapat disimpulkan bahwa semakin tinggi academic self-efficacy yang dimiliki maka akan semakin rendah academic burnout mahasiswa yang sedang mengerjakan skripsi. Begitu juga sebaliknya, apabila academic self-efficacy yang dimiliki rendah, maka semakin tinggi academic burnout mahasiswa yang sedang mengerjakan skripsi. Hal ini sesuai dengan temuan penelitian terdahulu yang dilakukan oleh Rahmati (2015), Fitri dan Akmal (2017), dan Manuel, dkk. (2017) bahwa academic selfefficacy memiliki hubungan negatif dan signifikan dengan academic burnout. Berbeda dengan temuan Ugwu dkk, (2013) pada mahasiswa universitas di Nigeria menunjukkan academic self-efficacy berhubungan positif dengan academic burnout. 
Menghadapi tantangan dan hambatan yang dialami mahasiswa adalah bentuk proses yang melelahkan dan menyebabkan stres yang berat. Sesuai dengan penelitian sebelumnya Sigit (2019) dan Puspitaningrum (2018) menyatakan bahwa mahasiswa yang sedang mengerjakan skripsi menemui berbagai hambatan yang membuat mahasiswa mengalami lelah dan stres yang berat atau dengan kata lain disebut dengan academic burnout. Academic burnout dipengaruhi oleh beberapa faktor salah satunya yaitu academic self-efficacy. Hasil penelitian ini menunjukkan bahwa academic self-efficacy memiliki pengaruh sebesar 0,600 atau 60\%. Artinya, academic self-efficacy memiliki pengaruh yang cukup besar terhadap academic burnout. Hak tersebut dikarenakan academic self-efficacy memiliki pengaruh lebih dari 50\% terhadap academic burnout. Hasil tersebut sesuai dengan peneliti sebelumnya Duran, dkk (Durán dkk., 2006) dan Manuel, dkk (2017) menyatakan bahwa academic self-efficacy merupakan faktor prediktor penting yang dapat mempengaruhi academic burnout. Adapun alasan yang dapat diajukan menurut Manuel, dkk (2017) bahwa mahasiswa yang mengalami academic burnout dapat membedakan mahasiswa dengan beberapa tingkatan academic self-efficacy-nya.

Academic self-efficacy penting untuk dimiliki mahasiswa terutama yang sedang mengerjakan skripsi. Mahasiswa yang sedang mengerjakan skripsi rentan mengalami academic burnout. Academic selfefficacy dapat membuat mahasiswa meningkatkan minat mengerjakan tugas, memiliki karakter percaya diri dalam mengerjakan sesuatu, memiliki kesabaran dengan optimis dan pantang menyerah, memiliki resiliensi serta motivasi belajar (Mukti,dkk, 2019). Sehingga academic self-efficacy memberikan aspek positif dalam diri mahasiswa. Dengan adanya aspek positif tersebut membuat mahasiswa dapat mengatasi masalah dengan efektif. Sesuai dengan penelitian Fernández-Arata dkk. (2017) yang menyatakan bahwa academic self-efficacy merupakan faktor pelindung tehadap academic burnout.

Peneliti lain menyatakan bahwa academic self-efficacy mempengaruhi pemilihan individu, tujuan, reaksi emosional, usaha dan perlawanan (Rahmati, 2015). Hal tersebut dikarenakan academic self-efficacy yang tinggi membantu terciptanya ketenangan ketika menghadapi tugas yang berat. Akan tetapi academic self-efficacy yang rendah ketika menghadapi tugas yang berat mengarah pada berkembangnya stres, depresi, dan kesulitan mengatasi masalah (Rahmati, 2015; Arlinkasari \& Akmal, 2017). Mahasiswa yang memiliki self-efficacy yang tinggi cenderung menghasilkan dan menguji tindakan alternatif dikarenakan sebelumnya mengalami kegagalan. Sehingga penting untuk mengembangkan dan menumbuhkan academic self-efficacy. Hal tersebut dikarenakan academic self-efficacy sebagai penyangga, meskipun mahasiswa mengalami academic burnout (Ugwu, dkk, 2013).

\section{S I M P U L A N}

Besarnya pengaruh academic self-efficacy terhadap academic burnout yaitu sebesar $60 \%$ dan $40 \%$ dipengaruhi oleh faktor lainnya. Pengaruh bersifat negatif yang artinya semakin tinggi academic selfefficacy, maka semakin rendah academic burnout mahasiswa yang sedang mengerjakan skripsi dan sebaliknya semakin rendah academic self-efficacy maka semakin tinggi academic burnout mahasiswa yang sedang mengerjakan skripsi.

Saran kepada mahasiswa yang mengalami burnout, ada baiknya untuk beristirahat atau refreshing sejenak. Selain itu melakukan kegiatan seperti hobi juga dapat membantu untuk mengurangi tingkat burnout bagi mahasiswa. Mahasiswa yang mengalami academic burnout ketikamengerjakan skripsi dapat mencari jalan keluar lewat komunikasi dengan dosen pembimbing. Kepada penelitian selanjutnya, diharapkan dapat mengembangkan penelitian ini menggunakan metode lain, sehingga dapat lebih dalam mengetahui faktor-faktor yang menyebabkan burnout, dan juga bagi peneliti 
selanjutnya, diharapkan dapat memperluas responden penelitian, sehingga dapat mengetahui tingkat burnout pada mahasiswa jurusan lain dalam mengerjakan skripsi.

Serta saran kepada fakultas hendaknya lebih memperhatikan mahasiswa yang sedang mengerjakan skripsi. Masalah yang dialami mahasiswa yang sedang mengerjakan skripsi kurang nampak dikarenakan tidak adanya wadah mahasiswa yang sedang mengerjakan skripsi untuk mengatasi masalah tersebut. Misalnya kegiatan training untuk meningkatkan academic self-efficacy mahasiswa, sehingga mahasiswa yang sedang mengerjakan skripsi lebih siap menghadapi masalah ketika mengerjakan skripsi dan tingkat academic burnout akan berkurang.

\section{U C A P A N T ER IMAKASIH}

Penulis mengucapkan terimakasih kepada mahasiswa Fakultas Psikologi Universitas Airlangga yang telah berpartisipasi dalam penelitian ini sehingga penelitian ini dalam pelaksanaannya dapat selesai.

\section{DEKLARASI POTENSI TERJADINYA KONFLIK KEPENTINGAN}

Ayu Anggraini Wasito dan Nono Hery Yoenanto tidak bekerja, menjadi konsultan, memiliki saham, atau menerima dana dari perusahaan atau organisasi manapun yang mungkin akan mengambil untung dari diterbitkannya naskah ini.

\section{PUST AKA ACUAN}

Arcelo, A. A., \& Sanyal, B. C. (1987). Employment and Career Opportunities After Graduation. International Institute for Education Planning.

Arlinkasari, F., \& Akmal, S. Z. (2017). Hubungan antara School Engagement, Academic Self-Efficacy dan Academic Burnout pada Mahasiswa. Humanitas (Jurnal Psikologi), 1(2), 81. https://doi.org/10.28932/humanitas.v1i2.418

Bandura, A. (1997). Self-Efficacy: The Exercise of Control. W. H. Freeman and Company.

Durán, A., Extremera, N., Rey, L., Fernández-Berrocal, P., \& Montalbán, F. M. (2006). Predicting academic burnout and engagement in educational settings: Assessing the incremental validity of perceived emotional intelligence beyond perceived stress and general self [Data set]. Dalam Https://www.researchgate.net/publication/6509295 (Vol. 18, hlm. 158-164). https://doi.org/10.1037/t01392-000

Fernández-Arata, M., Dominguez-Lara, S. A., \& Merino-Soto, C. (2017). Single-item academic burnout and its relationship with academic self-efficacy in college students. Enfermería Clínica (English Edition), 27(1), 60-61. https://doi.org/10.1016/j.enfcle.2016.07.001

Hu, Q., \& Schaufeli, W. B. (2009). The Factorial Validity of the Maslach Burnout Inventory-Student Survey in China. Psychological Reports, 105(2), 394-408. https://doi.org/10.2466/PR0.105.2.394-408

Idntimes. (2020, Juni 19). Dear Mahasiswa, Ini 5 Manfaat Kalau Kamu Lulus Kuliah Tepat Waktu. https://www.idntimes.com/life/education/rivandi-pranandita-putra/manfaat-kalau-kamululus-kuliah-tepat-waktu-c1c2/5

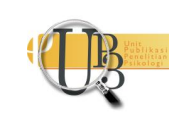


Julita. (2015). Faktor-faktor Penghambat Dalam Penyelesaian Skripsi Mahasiswa di Jurusan Kesejahteraan Keluarga [Skripsi]. Universitas Negeri Padang.

Khairani, Y., \& Ifdil, I. (2015). Konsep Burnoutpada Mahasiswa Bimbingan dan Konseling. Konselor, 4(4), 208. https://doi.org/10.24036/02015446474-0-00

Maslach, C., Schaufeli, W. B., \& Leiter, M. P. (2001). Job Burnout. Annual Review of Psychology, 52(1), 397422. https://doi.org/10.1146/annurev.psych.52.1.397

Mukti, B. (2019). Faktor-faktor yang mempengaruhi efikasi diri akademik. 7.

Neuman, W. L. (2007). Basic of Social Sosial Research Qualitative and Quantitative Approaches. 2nd Edition. Pearson Education, Inc.

Prianto, F. X. R. (2010). Efikasi Diri Pada Mahasiswa Psikologi Universitas Sanata Dharma Yang Sedang Mengerjakan Skripsi. 103.

Puspitaningrum, K. (2018). Pengaruh Dukungan Sosial Orang Tua Terhadap Burnout Pada Mahasiswa Dalam Mengerjakan Skripsi. 11.

Rahmati, Z. (2015). The Study of Academic Burnout in Students with High and Low Level of Self-efficacy. Procedia -Social and Behavioral Sciences, 171, 49-55. https://doi.org/10.1016/j.sbspro.2015.01.087

Ristekdikti. (2019, April 12). Pangkalan Data Pendidikan Tinggi. [Ristekdikti.com]. https://forlap.ristekdikti.go.id/perguruantinggi/detail/NUFBREYzREYtRDBGOC00QTE3LUJER kQtNjEwOEZDNUNFNDA1

Sigit, N. (2019). Hubungan Antara Distres Menghadapi Skripsi Dan Burnout Menghadapi Skripsi Pada Mahasiswa [Skripsi]. Universitas Sanata Dharma.

Sugiyono. (2015). Metode Penelitian Pendidikan: Pendektan Kuantitatif dan Kuantitatif dan R\&D. Alfabeta, cv.

Ugwu, F. O. (2013). Exploring The Relationships Between Academic Burnout, Self-Efficacy and Academic Engagement Among Nigerian College Students. The African Symposium, 13(2), 9. 